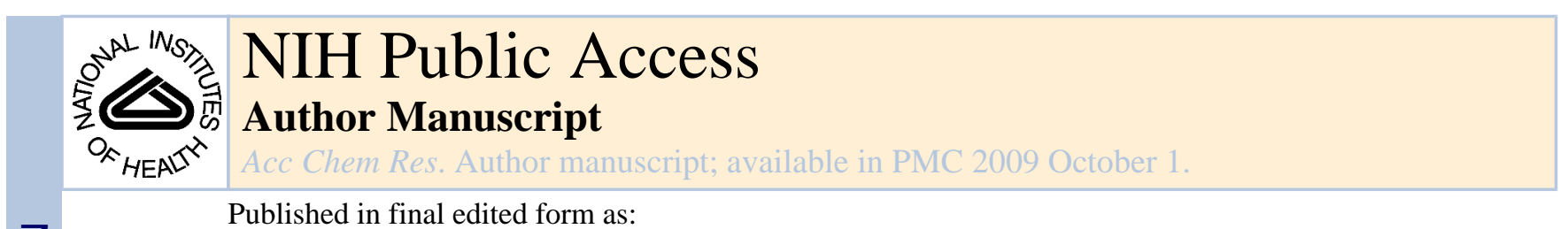

Published in final edited form as:

Acc Chem Res. 2008 October ; 41(10): 1399-1408. doi:10.1021/ar800009n.

\title{
Foldamers with Heterogeneous Backbones
}

\author{
W. Seth Horne and Samuel H. Gellman * \\ Department of Chemistry, University of Wisconsin, Madison, WI 53706
}

\section{Conspectus}

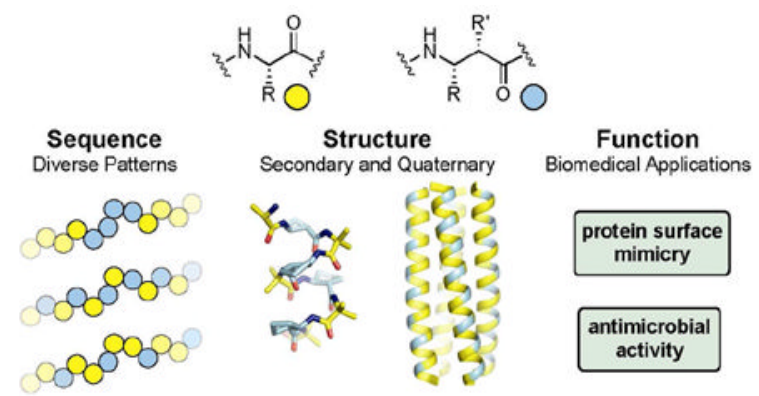

The functions carried out by proteins and nucleic acids provide the foundation for life, and chemists have begun to ask whether it is possible to design synthetic oligomers that approach the structural and functional complexity of these biopolymers. The study of foldamers, non-natural oligomers with discrete folding propensities, has demonstrated that a variety of synthetic backbones can show biopolymer-like conformational behavior. Early work in this area focused on oligomers comprised of a single type of monomer subunit, but recent efforts have highlighted the potential of mixed or "heterogeneous" backbones to expand the structural and functional repertoire of foldamers. In this Account, we illustrate the promise of heterogeneous backbone foldamers by focusing on examples containing both $\alpha$ - and $\beta$-amino acid residues.

The use of heterogeneous backbone foldamers offers advantages over homogeneous backbone counterparts, including access to many new molecular shapes, based on variations in the stoichiometries and patterns of subunit combination, and improved prospects for side chain diversification. Recent efforts to develop $\alpha / \beta$-peptide foldamers can be divided into two conceptually distinct classes. The first includes entities prepared by a "block" strategy, in which $\alpha$-peptide segments and $\beta$-peptide segments are combined to form a hybrid oligomer. The second class encompasses designs in which $\alpha$ - and $\beta$-amino acid monomers are interspersed in a regular pattern throughout an oligomer sequence. A variety of secondary structures has been generated from $\alpha / \beta-$ peptides via these approaches. Helical secondary structures available to $\alpha / \beta$-peptides have recently been parlayed into higher order structure, specifically, helix bundle quaternary structure.

Desirable biological functions have been elicited from $\alpha / \beta$-peptide foldamers. Efforts to mimic naturally occurring host-defense $\alpha$-peptides have yielded new antimicrobial agents and led to a reexamination of the long-held views regarding structure-activity relationships among $\alpha$-peptides and other amphiphilic oligomers. Foldamers offer new platforms for mimicry of molecular surfaces involved in specific protein-protein recognition events; recent achievements with $\alpha / \beta$-peptide inhibitors of protein-protein interactions involved in apoptotic signaling have revealed benefits of heterogeneous backbones relative to homogeneous backbones for foldamer-based designs. These initial successes in the development of $\alpha / \beta$-peptides with specific biological activities highlight the

E-mail: gellman@chem.wisc.edu. 
potential of heterogeneous backbone foldamers for biomedical applications and provide guidelines for the future work on new target functions.

\section{Introduction}

Foldamers are unnatural oligomers that display conformational propensities akin to those of proteins and nucleic acids, the oligomers that play starring roles in living systems. ${ }^{1}$ The relationship between folding and function among proteins has long been a source of fascination to the molecularly inclined scientist. The interplay between $\alpha$-amino acid residue sequence and the three-dimensional arrangement of these subunits that results from adoption of a specific conformation enables proteins to manifest an extraordinary range of functions. Chemists have been drawn to ask whether other backbones, containing subunits that were not selected by biological evolution, might be competent to support recognition, catalysis or assembly activities comparable to those displayed by folding biopolymers. Since many of these activities appear to require precise spatial positioning of key functional groups ("side chains"), foldamer studies often begin with an effort to determine whether a particular family of oligomers has any tendency to adopt specific shapes.

Many oligomeric backbones have been evaluated as potential foldamers since the mid-1990s. $2-5$ A majority of the foldamers studied to date are analogous to their biopolymer progenitors in that all subunits fall within a single class. Thus, for example, $\beta$-peptide foldamers contain exclusively $\beta$-amino acid residues, and $m$-phenyleneethynylene foldamers contain exclusively meta-linked phenylacetylene subunits. We refer to these systems as having "homogeneous" backbones. Recently, a number of research groups have turned their attention to foldamers with "heterogeneous" backbones, i.e., foldamers that contain more than one type of subunit. This Account is intended to highlight the promise of heterogeneous backbones for foldamer design and application. We will focus on examples that feature combinations of $\alpha$ - and $\beta$-amino acid residues (Figure 1), collectively referred to as " $\alpha / \beta$-peptides," because these are presently the best understood foldamers with heterogeneous backbones.

Nature occasionally slips a $\beta$-amino acid residue in among $\alpha$-residues, as in the cyclic depsipeptide Dolastatin 11 (Figure 2), which contains a $\beta$-residue (and a $\gamma$-residue) along with the $\alpha$-residues. ${ }^{6}$ Analogously, several research groups have designed peptides in which one or two $\beta$-residues are placed among $\alpha$-residues. Karle et al. reported one of the earliest examples, a cyclo-tetrapeptide with an $\alpha-\beta-\alpha-\beta$ backbone pattern. ${ }^{7,8}$ Balaram et al. have thoughtfully reviewed the diversification of peptidic backbones via insertion of single extended amino acid residues into $\alpha$-peptide contexts.

\section{Advantages of heterogeneous backbones}

Foldamer design based on heterogeneous backbones offers at least two benefits relative to an exclusive reliance on homogeneous backbones. First, for a given set of monomer classes, the number of candidate foldamer backbones is vastly larger if we include heterogeneous backbones than if we are limited to homogeneous backbones. If, for example, we consider only $\alpha$ - and $\beta$-amino acids as building blocks, then the homogeneous approach limits us to $\alpha$-peptides or $\beta$-peptides. The heterogeneous approach, in contrast, allows many different combinations (e.g., $\alpha-\beta-\alpha-\beta-\alpha-\beta \ldots, \alpha-\alpha-\beta-\alpha-\alpha-\beta \ldots, \alpha-\beta-\beta-\alpha-\beta-\beta \ldots, \alpha-\alpha-\beta-\beta \ldots$, to name just a few). Each of these heterogeneous backbones offers a potentially distinctive way to project sets of side chains in space. By analogy to proteins, interesting and valuable foldamer activities are likely to depend upon achieving a specific three-dimensional arrangement of functional groups; therefore, the more distinct shapes we can generate with foldamers, the better our prospects for realizing any particular activity. 
The availability of multiple, complementary oligomeric skeletons may be necessary for generating a broad array of foldamer functions, but scaffold variability is not sufficient for this goal; one must also be able to decorate the scaffolds with diverse side chains. The heterogeneous backbone approach can greatly facilitate the generation of foldamer sets with broad side chain diversity. This advantage is particularly evident when $\alpha$-amino acids constitute one of the building block types in a foldamer backbone, because a wide variety of protected $\alpha$-amino acids is commercially available. Having to synthesize every new building block, especially if the building blocks must be enantiomerically pure, represents a substantial practical barrier to function-oriented development of new foldamers. Combining $\alpha$-amino acids with other building blocks offers the prospect of purchasing some or all of the side chain diversity in a ready-to-use form. One can envision using a few types of rigidified unnatural building blocks to promote a specific folded conformation while relying on $\alpha$-residues to provide many different side chain functional groups.

\section{New secondary structures from systematic combination of $\alpha$ - and $\beta$-residues}

Several research groups have undertaken conformational analysis and function-based design with $\alpha / \beta$-peptides in the past few years. Early on we recognized two distinct approaches to heterogeneous backbone foldamers. ${ }^{10}$ One approach involves oligomers comprised of multiple "blocks," each containing different subunits, and each fulfilling different structural and/or functional roles. The other approach is to examine backbones with a regular pattern of subunit alternation. As discussed below, these two approaches can be combined in various ways.

The "block" approach to combining $\alpha$ and $\beta$ subunits arose from our efforts to study sheet secondary structure in pure $\beta$-peptide foldamers. $\alpha$-Peptide research had shown that the minimum increment of sheet secondary structure is a hairpin, in which strand-forming segments are connected via a reverse turn. We initially used a reverse turn segment from the $\alpha$-peptide realm to link $\beta$-residues intended form sheet secondary structure (Figure 3A). ${ }^{11}$,

12 A similar approach had previously been used by Clardy, Schreiber et al. in their pioneering study of unsaturated $\gamma$-amino acid residue folding propensities. ${ }^{13}$ We subsequently created a complementary heterogeneous hairpin, with a $\beta$-peptide reverse turn and $\alpha$-peptide strands (Figure 3B). ${ }^{10}$ Raines et al. have reported an impressive implementation of the block approach by replacing a reverse turn in the protein ribonuclease with a $\beta$-peptide reverse turn without loss of catalytic activity. ${ }^{14}$ One can imagine even more ambitious versions of this experimental strategy in which, for example, an $\alpha$-helical segment of a protein is replaced by a foldamer helix.

The first systematic structural studies of linear oligomers with backbone alternation of $\alpha$ - and $\beta$-residues were conducted independently by Zerbe, Reiser et al. ${ }^{15}$ and by our group. ${ }^{16}$ The European team used 2D NMR analysis to document helix formation by $\alpha / \beta$-peptides such as 1, containing L-Ala residues alternating with 3-substituted cis-2-

aminocyclopropanecarboxylic acid residues. Heptamer $\mathbf{1}$ in methanol was shown to adopt a helix defined by $i \rightarrow i-2 \mathrm{C}=\mathrm{O} \cdots \mathrm{H}-\mathrm{N}$ H-bonds (Figure $4 \mathrm{~A}$ ). This structural work was inspired by earlier pharmacological studies, which showed that incorporation of a single cis-2-

aminocyclopropanecarboxylic acid residue into a peptide corresponding to the C-terminus of neuropeptide $\mathrm{Y}$ gave rise to substantial affinity and unique selectivity toward the natural receptor proteins. ${ }^{17}$ Interestingly, this biological activity required the $\beta$-residue absolute configuration that did not give rise to a discrete folding propensity when paired with L- $\alpha$ residues in the subsequent structural studies.

Our initial studies of alternating $\alpha / \beta$-peptides arose from a desire to expand the range of foldamer scaffolds beyond those previously shown for homogeneous $\beta$-peptide backbones. 
Our $\beta$-peptide work had demonstrated the unique ability of conformationally preorganized residues (Figure 1) to promote stable secondary structures in short oligomers, with distinct $\beta$ peptide helices generated by sequences containing either trans-2-aminocyclohexanecarboxylic acid (ACHC) or trans-2-aminocyclopentanecarboxylic acid (ACPC). ${ }^{3}$ We wondered whether combining these preorganized $\beta$-residues with $\alpha$-residues would lead to new foldamers. This question was addressed by preparing hexamers and octamers containing $(S, S)$-ACPC or $(S, S)$ ACHC residues alternating with either L- or D- $\alpha$-amino acid residues. Evaluation of these oligomers by 2D NMR in methanol solution revealed that only the combination of $(S, S)$-ACPC and $\mathrm{L}-\alpha$-amino acid residues, as in $\mathbf{2}$, gave rise to NOEs between backbone protons from residues that are not adjacent in sequence. ${ }^{16}$ Such non-sequential NOEs provide the clearest evidence of folding in solution.

The medium-range NOEs observed for $\alpha / \beta$-peptide $\mathbf{2}$ in methanol could be explained by two distinct hypotheses. (1) The $\alpha / \beta$-peptides adopt a single helical conformation containing unusual bifurcated $\mathrm{H}$-bonds, with each backbone $\mathrm{C}=\mathrm{O}$ group simultaneously interacting with two backbone $\mathrm{N}-\mathrm{H}$ groups and vice versa (simultaneous $i \rightarrow i+3$ and $i \rightarrow i+4 \mathrm{C}=\mathrm{O} \cdots \mathrm{H}-\mathrm{N} \mathrm{H}-$ bonding). (2) The $\alpha / \beta$-peptides interconvert rapidly on the NMR time scale between two different helical conformations, one involving $i \rightarrow i+3$ and the other $i \rightarrow i+4 \mathrm{C}=\mathrm{O} \cdots \mathrm{H}-\mathrm{N} \mathrm{H}-$ bonds; these conformations are designated the 11-helix and the 14/15-helix, respectively, based on H-bonded ring size (Figure 4B, C). We favored hypothesis (2) in light of the folding behavior of $\alpha$-peptides and proteins. The $i \rightarrow i+3$ and $i \rightarrow i+4 \mathrm{C}=\mathrm{O} \cdots \mathrm{H}-\mathrm{N}$ H-bonding patterns are commonly observed for the $\alpha$-peptide backbone, corresponding to $3_{10}$-and $\alpha$-helical secondary structure, respectively. ${ }^{18}$ There is evidence that these two H-bonding patterns can rapidly interconvert in helix-forming $\alpha$-peptides, but bifurcated $\mathrm{H}$-bonds are rare in $\alpha$-peptide helices.

Crystallographic analysis of many $\alpha / \beta$-peptides, including 3-5, has provided strong support for the hypothesis of interconverting helical conformations (Figure 5). ${ }^{19,20}$ Octamer 3 displays purely 11-helical secondary structure in the solid state, while nonamer 5 displays purely 14/15helical secondary structure. Octamer $\mathbf{4}$, which differs subtly from $\mathbf{3}$, is mostly 11 -helical in the crystalline form, but the $\mathrm{N}$-terminal Boc carbonyl engages in a 14-membered ring $\mathrm{H}$-bond. Thus, although 4 seems to be torn between the 11- and 14/15-helical conformations in the solid state, the observed helix does not contain any bifurcated H-bonds. Two-dimensional NMR data acquired for 15 -mer $\alpha / \beta$-peptides indicate that at this length the $14 / 15$-helix is favored over the 11-helix. ${ }^{21,22}$ Thus, these 1:1 $\alpha / \beta$-peptides behave comparably to $\alpha$-peptides, in which both $310^{-}$and $\alpha$-helical conformations populated among shorter oligomers, but the $\alpha$-helix is favored when the backbone is lengthened. 18

The variety of helical secondary structures available to $\alpha / \beta$-peptides with $1: 1 \alpha: \beta$ alternation has been expanded by Sharma, Kunwar et al., who provided evidence for a helix with a "mixed" $\mathrm{H}$-bonding pattern in oligomers such as $\mathbf{6}$ in chloroform solution. ${ }^{23,24} \alpha / \beta$-Peptide 6 is heterochiral because it contains D- $\alpha$-amino acid residues and $\beta^{3}$-residues derived from L- $\alpha$ residues; by analogy, $\alpha / \beta$-peptide 2 is homochiral. The $9 / 11$-helix identified by this group contains two distinct types of backbone $\mathrm{C}=\mathrm{O} \cdots \mathrm{H}-\mathrm{N}$ H-bonds that have opposite orientations relative to the backbone direction (Figure 4D). Based on $2 \mathrm{D}$ NMR analysis of $\alpha / \beta$-peptides containing $\beta^{3}$-residues and $\alpha$-aminoisobutyric acid in methanol, Seebach et al. concluded that this type of $\alpha / \beta$-peptide can adopt a 14/15-helix-like conformation that, curiously, lacks intramolecular H-bonds. ${ }^{25}$ We suspect that these flexible $\alpha / \beta$-peptides simply do not populate the $14 / 15$-helix to a large extent, because $\beta^{3}$ residues have a much lower $\alpha / \beta$-peptide helix propensity than do cyclic $\beta$ residues. ${ }^{20}$ Jagadeesh et al. have recently reported on the folding of $\alpha / \beta$-peptides containing a cyclic carbohydrate-derived $\beta$-residue. ${ }^{26}$ NMR data obtained in both chloroform and DMSO revealed NOEs that are consistent with the formation of $i \rightarrow i+3$ and $i \rightarrow i+4 \mathrm{C}=\mathrm{O} \cdots \mathrm{H}-\mathrm{N}$ H-bonds in 7 and related $\alpha / \beta$-peptides, which suggests population of both 11- and 14/15-helical conformations. Computational modeling of helix formation for 
oligomers with the 1:1 $\alpha: \beta$ backbone enables direct comparisons among helical secondary structures reported to date and others that have not yet been documented experimentally. 27 , 28

Foldameric behavior is not limited to $\alpha / \beta$-peptides with a $1: 1 \alpha: \beta$ residue alternation. We recently found that both $2: 1$ and 1:2 $\alpha: \beta$ backbone patterns (such as $\mathbf{8}$ and $\mathbf{9}$, respectively) support helix formation in short oligomers. ${ }^{29}$ Medium-range NOEs observed for these $\alpha / \beta$ peptides in methanol are consistent with population of two helical conformations in each case, one helix containing $i \rightarrow i+3$ and the other $i \rightarrow i+4 \mathrm{C}=\mathrm{O} \cdots \mathrm{H}-\mathrm{N}$ H-bonds. Crystallographic analysis of short 1:2 and 2:1 $\alpha / \beta$-peptides has provided high-resolution data for the $i \rightarrow i+3$ $\mathrm{C}=\mathrm{O} \cdots \mathrm{H}-\mathrm{N}$ H-bonded helices (Figure 6), but not yet for the $i \rightarrow i+4 \mathrm{H}$-bonded counterparts.

Overall, the structural data we and others have obtained with short oligomers suggest that the propensity to form $i \rightarrow i+3$ and/or $i \rightarrow i+4 \mathrm{C}=\mathrm{O} \cdots \mathrm{H}-\mathrm{N}$ H-bonded helices may be a common feature of foldamers that contain homochiral $\alpha$ - and $\beta$-amino acid residues, for most $\alpha: \beta$ proportions and sequence patterns. As already noted, these two intramolecular H-bonding patterns are well-known among $\alpha$-peptides and proteins, where they are seen in $310^{-}$and $\alpha$ helices. ${ }^{18}$ In light of the considerable intrinsic flexibility of $\beta^{3}$-residues, we wondered whether homochiral oligomers containing both $\alpha$ - and $\beta^{3}$-residues might be induced to adopt $\alpha$-helixlike $i \rightarrow i+4 \mathrm{C}=\mathrm{O} \cdots \mathrm{H}-\mathrm{N} \mathrm{H}-$ bonded secondary structure based on information encoded in a specific side chain sequence. We have explored this possibility in the context of $\alpha / \beta$-peptide self-assembly.

\section{Helix bundle quaternary structure formation involving $\alpha / \beta \beta$-peptides}

Most foldamer research to date has focused on secondary structure, but creating foldamers with discrete tertiary structure has long been recognized as a major aim. ${ }^{1}$ Conformational order at this level is important not only as a fundamental structural goal, but also as a prelude to developing foldamers with sophisticated functions, such as catalysis, which, among proteins, generally require discrete tertiary folding. Efforts to generate foldamer tertiary structure have built upon the hierarchical design strategy put forward by DeGrado et al. for the de novo development of $\alpha$-peptides with helix bundle tertiary structure. ${ }^{30}$ Several groups have reported homogeneous $\beta$-peptides that accomplish the first step of the hierarchical approach, selfassembly to discrete helix bundles in aqueous solution. ${ }^{31-33}$ In the realm of heterogeneous backbone foldamers, we have demonstrated helix bundle quaternary structure formation in two distinct systems.

$\alpha / \beta$-Peptides 10 and 11 (Figure 7) were designed by extrapolation from a natural selfassembling sequence embedded in the yeast protein GCN4. ${ }^{34}$ GCN4-p1, a 33-residue $\alpha$ peptide segment from the native protein, folds to form a coiled-coil dimer. ${ }^{35} \alpha / \beta$-Peptide 10 displays the side chain sequence of GCN4-p1 on a heterogeneous $\alpha \alpha \beta \alpha \alpha \alpha \beta$ backbone; each $\beta^{3}$-residue bears the side chain of the $\alpha$-residue it replaces. The pattern of $\alpha \rightarrow \beta^{3}$ replacement in $\mathbf{1 0}$ is attuned to the heptad repeat that is commonly observed among $\alpha$-peptide sequences that form helix bundles. ${ }^{36}$ Such sequences usually contain hydrophobic side chains at the first and fourth positions of each heptad, which are conventionally designated positions $a$ and $d$ of an $a b c d e f g$ repeat. Side chains from a/d heptad positions, upon $\alpha$-helical folding, form of a hydrophobic "stripe" on one side of the helix and pack against one another in the core of the helix bundle, providing the driving force for self-assembly. The $\beta^{3}$-residues in $\mathbf{1 0}$ are placed at the $b$ and $f$ positions of each heptad. Thus, upon formation of an $i \rightarrow i+4 \mathrm{C}=\mathrm{O} \cdots \mathrm{H}-\mathrm{N} \mathrm{H}$-bonded helix, 10 displays a stripe of hydrophobic side chains provided by natural $\alpha$-residues and, on the opposite side of the helix, a stripe of $\beta^{3}$-residues. The crystal structure of $\mathbf{1 0}$ shows a threehelix bundle with the $a / d$ side chains in the core and the $b / f \beta$-residues at the periphery, as expected. The helical conformation of $\mathbf{1 0}$ overlays very well on the $\alpha$-helical conformation of 
the GCN-p1 $\alpha$-peptide; however, the assembly behaviors of the $\alpha$ - and $\alpha / \beta$-peptides diverge. The stoichiometry of assembly differs (dimer vs. trimer) as does the stability of the helix bundles, with much weaker self-association of the $\alpha / \beta$-peptide relative to the $\alpha$-peptide.

$\alpha / \beta$-Peptide 11 arises from $b / f \alpha \rightarrow \beta^{3}$ modification of GCN4-pLI, a GCN4-p1 mutant that forms a very stable four-helix bundle. ${ }^{37}$ The crystal structure of $\mathbf{1 1}$ reveals a four-helix bundle that is very similar to the quaternary structure formed by GCN4-pLI in the crystalline state. The helix bundle of $\mathbf{1 1}$ is highly resistant to thermal disruption; however, unlike GCN4-pLI, which forms a tetramer in solution, $\alpha / \beta$-peptide $\mathbf{1 1}$ appears to form a trimer in solution. Thus, for both $\mathbf{1 0}$ and 11, systematic $\alpha \rightarrow \beta^{3}$ modification at selected positions yields an $\alpha / \beta$-peptide with selfassembly behavior that is reminiscent of but not identical to that of the starting $\alpha$-peptide.

The crystallographic data for $\alpha / \beta$-peptides 10 and 11, along with those for a purely $\beta$-peptide helix bundle, ${ }^{31}$ provide the first high-resolution insight on foldamer quaternary structure. The behavior of $\mathbf{1 0}$ and $\mathbf{1 1}$ raises many questions that provide a basis for future studies of $\alpha / \beta$ peptides and perhaps other heterogeneous backbone foldamers that bear the side chain sequence of an $\alpha$-peptide prototype. In particular, it will be interesting to see whether "sequence-based" oligomer designs provide a general source of foldamers with interesting functions.

In a second approach to helix bundle self-assembly, we have pursued a "block" strategy in which the quaternary structure contains both $\alpha$-peptide and $\alpha / \beta$-peptide components. Previous work of Kim et al. showed that acidic $\alpha$-peptide $\mathbf{1 2}$ co-assembles with a complementary basic $\alpha$-peptide to form 2:2 tetramer. ${ }^{38}$ The $\alpha / \beta$-peptide $14 / 15$-helix features an approximate heptad repeat (i.e., seven residues comprise about two helical turns). We therefore designed basic $\alpha /$ $\beta$-peptide $\mathbf{1 3}$ to co-assemble with acidic $\mathbf{1 2}$ into a hetero-helix bundle quaternary structure (Figure 8). ${ }^{39} \mathrm{We}$ included cyclically constrained residues in $\alpha / \beta$-peptide $\mathbf{1 3}$ to encourage formation of the 14/15-helical conformation. CD and AU measurements indicate that mixing $\mathbf{1 2}$ and $\mathbf{1 3}$ in aqueous solution leads to a cooperatively folded 2:2 tetrameric assembly with high thermal stability and extensive helicity in the individual molecules.

\section{$\alpha / \beta$-Peptides with biological functions}

Systematic study of $\alpha / \beta$-peptides with regular backbone repeat patterns is a recent phenomenon, as indicated above, but already these heterogeneous backbones have been used to develop foldamers with interesting biological activities. Biomedical application of $\alpha$-peptides can be limited by rapid degradation in vivo. Foldamers composed exclusively of unnatural subunits, such as $\beta$-peptides, are highly resistant to proteases, ${ }^{40}$ but what about $\alpha / \beta$-peptides? It has long been known that placing a single $\beta$-residue within an $\alpha$-residue context can substantially retard proteolytic cleavage of nearby peptide bonds. ${ }^{41}$ Based on this precedent, it is not surprising that oligomers featuring a 1:1 $\alpha / \beta$ backbone are highly resistant to proteolysis, although slow cleavage of amide bonds between $\alpha$ and $\beta$ residues can be detected in some cases. ${ }^{22,42}$

Our first effort at eliciting function from $\alpha / \beta$-peptides involved evaluating the 11 - and the $14 / 15$-helices of $1: 1 \alpha / \beta$-peptides for their ability to mimic $\alpha$-helical host-defense peptides. 21,22 Natural host defense peptides are produced by eukaryotes as part of the innate immune response to microbial infection. ${ }^{43}$ When they encounter bacterial membrane surfaces, hostdefense peptides such as the magainins adopt an $\alpha$-helical conformation. This folding leads to global segregation of lipophilic and hydrophilic side chains, which is thought to be responsible for disruption of the bacterial membrane. We previously found that $\beta$-peptides that form globally amphiphilic helices mimic the antibacterial activity of natural host-defense peptides. 44 Surprisingly, however, our $\alpha / \beta$-peptide studies revealed that formation of a globally amphiphilic helix is not required for host-defense peptide mimicry. This discovery has important implications for development of new antibacterial materials because an oligomer 
that achieves global segregation of lipophilic and hydrophilic side chains in a helical conformation must be synthesized in stepwise fashion, which is expensive. Our $\alpha / \beta$-peptide findings led us to suggest that random copolymers of lipophilic and hydrophilic subunits might be able to mimic host-defense peptides, and we have recently provided experimental support for this hypothesis. 45

A major function-oriented goal of foldamer research has been to develop inhibitors of biomedically important interactions between specific proteins. In many cases, this goal has been difficult to achieve with the small molecule-based approach that is the staple of traditional medicinal chemistry. ${ }^{46}$ Foldamers offer the prospect of mimicking the surface features of one of the interacting partners by appropriate placement of side chains on an unnatural folded backbone while enhancing resistance to enzymatic degradation relative to a conventional $\alpha$ peptide.

Protein-protein interactions in which one partner contributes a single $\alpha$-helix to the interface are attractive for foldamer-based inhibitor development, because a variety of foldamer helices can be predictably generated by proper choice of subunits. Interactions between pro- and antiapoptotic members of the Bcl-2 protein family are intriguing in this regard. ${ }^{47}$ This protein network controls cellular responses to various death stimuli, and over-expression of antiapoptotic Bcl-2 family members is associated with cancer. The anti-apoptotic family members, including Bcl-2, Bcl- $\mathrm{x}_{\mathrm{L}}$ and Mcl-1, present a long cleft that can accommodate an $\alpha$-helical BH3 domain from a pro-apoptotic family member, such as Bak or Bad. BH3 domain sequences feature the heptad repeat discussed above, with hydrophobic side chains occurring in $i+3 / i+4$ patterns. There are four highly conserved hydrophobic positions shared among BH3 domain sequences, and the side chains of these residues bind into pockets along the BH3-recognition clefts of complementary anti-apoptotic Bcl-2 family members. 48,49

Our initial efforts to develop foldamers that could mimic a natural BH3 domain focused on helical $\beta$-peptides and 1:1 $\alpha / \beta$-peptides. Despite extensive effort, we were unable to identify any 12 -helical or 14 -helical $\beta$-peptides or 11 -helical $\alpha / \beta$-peptides that bound tightly to the $\mathrm{BH} 3$ recognition cleft of $\mathrm{Bcl}-\mathrm{x}_{\mathrm{L}}$. 14/15-Helical designs with modest affinity for $\mathrm{Bcl}-\mathrm{x}_{\mathrm{L}}$ could be generated. Efforts to enhance binding by modifying the side chains on a purely $14 / 15$-helical scaffold were not productive, so we turned to a "diblock" design strategy. We found that $\alpha / \beta$ peptides containing both a $1: 1 \alpha: \beta$ block and a pure $\alpha$ block could be very effective ligands for the BH3-recognition cleft of Bcl- $\mathrm{x}_{\mathrm{L}}$. These studies ultimately led us to oligomer 14, which contains a nine-residue $\alpha / \beta$ segment followed by a six-residue $\alpha$ segment (Figure $9 \mathrm{~A}$ ). ${ }^{50}$ Oligomer 14 has an affinity for Bcl- $\mathrm{x}_{\mathrm{L}}\left(K_{i} \sim 1 \mathrm{nM}\right)$ that rivals the tightest-binding BH3-derived $\alpha$-peptides. Control experiments revealed that the bulk of the binding energy comes from the $\alpha / \beta$ segment rather than the $\alpha$ segment, and that binding to $\mathrm{Bcl}-\mathrm{x}_{\mathrm{L}}$ requires a specific $3 \mathrm{D}$ complementarity (the enantiomer of $\mathbf{1 4}$ does not bind). Docking calculations coupled with extensive side chain modification studies enabled us to propose a binding mode for the association of $\mathbf{1 4}$ with Bcl- $\mathrm{x}_{\mathrm{L}}$ (Figure 9B). ${ }^{51}$ Studies of a slightly modified $\alpha / \beta$-peptide show that this type of foldamer can block interactions between $\mathrm{Bcl}-\mathrm{x}_{\mathrm{L}}$ and complementary proapoptotic proteins in cell lysates. 51

The search for effective inhibitors of BH3 domain binding by Bcl- $\mathrm{x}_{\mathrm{L}}$ suggests important lessons for future efforts to design foldamers that antagonize specific protein-protein interactions. First, these results show that it is important to have access to many different foldamer scaffolds. In this example, only one of several foldameric helices was successful at mimicking the $\alpha$-helical prototype, and this success was limited to the $\mathrm{N}$-terminal portion of the target $\alpha$-helix. Second, for mimicry of extended protein surfaces, such as that displayed by an $\alpha$-helix of more than four turns, it may be necessary to combine multiple foldamer scaffolds. We would like to replace the $\alpha$-peptide segment of $\mathbf{1 4}$ with an unnatural backbone, to eliminate 
the proteolytic susceptibility in this region, but so far this effort has not succeeded. ${ }^{52}$ Presumably we need to use a new type of foldamer helix, perhaps one that has not yet been discovered. In support of this idea, we have recently applied the sequence-based design strategy, outlined above in the context of helix bundle quaternary structure, to create $\alpha / \beta$ peptide mimics of $\mathrm{BH} 3$ domains with $K_{i}$ values in the low $\mathrm{nM}$ range for $\mathrm{Bcl}-\mathrm{x}_{\mathrm{L}}$ and enhanced proteolytic stability. ${ }^{53}$ Thus, the third lesson (actually a restatement of the first) is that we must continue to explore new oligomers, both homogeneous and heterogeneous, for foldameric behavior.

\section{Future Prospects}

The study of $\alpha / \beta$-peptide foldamers is relatively recent, but already a range of interesting structural behavior has been documented. Our developing knowledge of $\alpha / \beta$-peptide conformational propensities has provided a basis for development of examples with specific biological activity. It is obvious that many new patterns of $\alpha$ - and $\beta$-residues remain to be explored in terms of both structure and function. More broadly, the rapid development of $\alpha /$ $\beta$-peptide chemistry illustrates the utility of the heterogeneous backbone concept in foldamer development.

Folding oligomers with other subunit mixtures have been described, and these examples provide further evidence that the heterogeneous backbone approach to foldamer design is valuable. Some of the reported systems interweave $\alpha$ - with $\gamma$ - or even larger amino acids. ${ }^{54}$ 56 These combinations have allowed researchers to take advantage of established conformation propensities of the $\alpha$ subunits, as in the early $\alpha / \gamma$-peptide work of Clardy, Schreiber et al., ${ }^{13}$ or to employ useful functional groups that are readily available among $\alpha$-amino acids, as in the $\alpha /$ cholate-peptide metal ion sensors of Zhao and Zhong. ${ }^{57}$ Other researchers have combined different types of unnatural residues, as illustrated by the pioneering aromatic amide oligomers of Hamilton et al., 58,59 the helices with tunable internal diameters of Gong et al. ${ }^{60}$ and the novel structures reported by Huc et al. ${ }^{4}$ Collectively, these and related studies suggest that a large universe of new foldamers with distinctive structural and functional properties awaits discovery.

\section{Acknowledgments}

The research from our laboratory discussed in this Account was supported by grants from the U.S. National Science Foundation and the U. S. National Institutes of Health.

\section{References}

1. Gellman SH. Foldamers: A manifesto. Acc Chem Res 1998;31:173-180.

2. Hill DJ, Mio MJ, Prince RB, Hughes TS, Moore JS. A field guide to foldamers. Chem Rev 2001;101:3893-4011. [PubMed: 11740924]

3. Cheng RP, Gellman SH, DeGrado WF. $\beta$-Peptides: From structure to function. Chem Rev 2001;101:3219-3232. [PubMed: 11710070]

4. Huc I. Aromatic oligoamide foldamers. Eur J Org Chem 2004:17-29.

5. Hecht, S.; Huc, I., editors. Foldamers: Structure, Properties, and Applications. Wiley-VCH; Weinheim: 2007.

6. Pettit GR, Kamano Y, Kizu H, Dufresne C, Herald CL, Bontems RJ, Schmidt JM, Boettner FE, Nieman RA. Isolation and structure of the cell growth inhibitory depsipeptides Dolastatins 11 and 12. Heterocycles 1989;28:553-558.

7. Karle IL, Handa BK, Hassall CH. The conformation of the cyclic tetrapeptide L-Ser(O-t- Bu)- $\beta$-AlaGly-L- $\beta$-Asp(OMe) containing a 14-membered ring. Acta Crystallogr, Sect B: Struct Sci 1975;B31:555-560. 
8. Pavone V, Lombardi A, D'auria G, Saviano M, Nastri F, Paolillo L, Di Blasio B, Pedone C. $\beta$-Alanine containing peptides: A novel molecular tool for the design of $\gamma$-turns. Biopolymers 1992;32:173-183. [PubMed: 1637991]

9. Chatterjee S, Roy RS, Balaram P. Expanding the polypeptide backbone: Hydrogen-bonded conformations in hybrid polypeptides containing the higher homologues of $\alpha$-amino acids. J R Soc Interface 2007;4:587-606. [PubMed: 17251160]

10. Huck BR, Fisk JD, Gellman SH. Promotion of sheet formation in $\alpha$-peptide strands by a $\beta$-peptide reverse turn. Org Lett 2000;2:2607-2610. [PubMed: 10990408]

11. Krauthäuser S, Christianson LA, Powell DR, Gellman SH. Antiparallel sheet formation in $\beta$-peptide foldamers: Effects of $\beta$-amino acid substitution on conformational preference. J Am Chem Soc 1997;119:11719-11720.

12. See also: Gopi HN, Roy RS, Raghothama SR, Karle IL, Balaram P. $\beta$-Hairpins generated from hybrid peptide sequences containing both $\alpha$ - and $\beta$-amino acids. Helv Chim Acta 2002;85:3313-3330.3330

13. Hagihara M, Anthony NJ, Stout TJ, Clardy J, Schreiber SL. Vinylogous polypeptides: An alternative peptide backbone. J Am Chem Soc 1992;114:6568-6570.

14. Arnold U, Hinderaker MP, Nilsson BL, Huck BR, Gellman SH, Raines RT. Protein prosthesis: A semisynthetic enzyme with a $\beta$-peptide reverse turn. J Am Chem Soc 2002;124:8522-8523. [PubMed: 12121081]

15. De Pol S, Zorn C, Klein CD, Zerbe O, Reiser O. Surprisingly stable helical conformations in $\alpha / \beta$ peptides by incorporation of $c i s-\beta$-aminocyclopropane carboxylic acids. Angew Chem Int Ed 2004;43:511-514.

16. Hayen A, Schmitt MA, Ngassa FN, Thomasson KA, Gellman SH. Two helical conformations from a single foldamer backbone: "Split personality" in short $\alpha / \beta$-peptides. Angew Chem Int Ed 2004;43:505-510.

17. Koglin N, Zorn C, Beumer R, Cabrele C, Bubert C, Sewald N, Reiser O, Beck-Sickinger AG. Analogues of neuropeptide $Y$ containing $\beta$-aminocyclopropane carboxylic acids are the shortest linear peptides that are selective for the $\mathrm{Y}_{1}$ receptor. Angew Chem Int Ed 2003;42:202-205.

18. Bolin KA, Millhauser GL. $\alpha$ and $3{ }_{10}$ : The split personality of polypeptide helices. Acc Chem Res 1999;32:1027-1033.

19. Choi SH, Guzei IA, Gellman SH. Crystallographic characterization of the $\alpha / \beta$-peptide $14 / 15$-helix. J Am Chem Soc 2007;129:13780-13781. [PubMed: 17949002]

20. Schmitt MA, Choi SH, Guzei IA, Gellman SH. Residue requirements for helical folding in short $\alpha /$ $\beta$-peptides: Crystallographic characterization of the 11-helix in an optimized sequence. J Am Chem Soc 2005;127:13130-13131. [PubMed: 16173725]

21. Schmitt MA, Weisblum B, Gellman SH. Unexpected relationships between structure and function in $\alpha, \beta$-peptides: Antimicrobial foldamers with heterogeneous backbones. J Am Chem Soc 2004;126:6848-6849. [PubMed: 15174837]

22. Schmitt MA, Weisblum B, Gellman SH. Interplay among folding, sequence, and lipophilicity in the antibacterial and hemolytic activities of $\alpha / \beta$-peptides. J Am Chem Soc 2007;129:417-428. [PubMed: 17212422]

23. Sharma GVM, Nagendar P, Jayaprakash P, Krishna PR, Ramakrishna KVS, Kunwar AC. 9/11 Mixed helices in $\alpha / \beta$ peptides derived from $C$-linked carbo- $\beta$-amino acid and L-Ala repeats. Angew Chem Int Ed 2005;44:5878-5882. 18.

24. Srinivasulu G, Kumar SK, Sharma GVM, Kunwar AC. 11/9-Mixed helices in the $\alpha / \beta$-peptides derived from alternating $\alpha$ - and $\beta$-amino acids with proteinogenic side chains. J Org Chem 2006;71:83958400. [PubMed: 17064011]

25. Seebach D, Jaun B, Sebesta R, Mathad RI, Flögel O, Limbach M, Sellner H, Cottens S. Synthesis, and helix or hairpin-turn secondary structures of 'mixed' $\alpha / \beta$-peptides consisting of residues with proteinogenic side chains and of 2-amino-2-methylpropanoic acid (Aib). Helv Chim Acta 2006;89:1801-1825.

26. Jagadeesh B, Prabhakar A, Sarma GD, Chandrasekhar S, Chandrashekar G, Reddy MS, Jagannadh B. Formation of left-handed helices in hybrid peptide oligomers with cis $\beta$-sugar amino acid and LAla as building blocks. Chem Commun 2007:371-373. 
27. Baldauf C, Günther R, Hofmann HJ. Theoretical prediction of the basic helix types in $\alpha, \beta$-hybrid peptides. Biopolymers 2006;84:408-413. [PubMed: 16506208]

28. Zhu X, Yethiraj A, Cui Q. Establishing effective simulation protocols for $\alpha$ - and $\alpha / \beta$-mixed peptides. I. QM and QM/MM models. J Chem Theory Comput 2007;3:1538-1549.

29. Schmitt MA, Choi SH, Guzei IA, Gellman SH. New helical foldamers: Heterogeneous backbones with 1:2 and 2:1 $\alpha$ : $\beta$-amino acid residue patterns. J Am Chem Soc 2006;128:4538-4539. [PubMed: 16594667]

30. Bryson JW, Betz SF, Lu HS, Suich DJ, Zhou HX, O’Neil KT, DeGrado WF. Protein design: A hierarchic approach. Science 1995;270:935-941. [PubMed: 7481798]

31. Daniels DS, Petersson EJ, Qiu JX, Schepartz A. High-resolution structure of a $\beta$-peptide bundle. J Am Chem Soc 2007;129:1532-1533. [PubMed: 17283998]

32. Cheng RP, DeGrado WF. Long-range interactions stabilize the fold of a non-natural oligomer. J Am Chem Soc 2002;124:11564-11565. [PubMed: 12296699]

33. Raguse TL, Lai JR, LePlae PR, Gellman SH. Toward $\beta$-peptide tertiary structure: Self-association of an amphiphilic 14-helix in aqueous solution. Org Lett 2001;3:3963-3966. [PubMed: 11720580]

34. Horne WS, Price JL, Keck JL, Gellman SH. Helix bundle quaternary structure from $\alpha / \beta$-peptide foldamers. J Am Chem Soc 2007;129:4178-4180. [PubMed: 17362016]

35. O'Shea EK, Klemm JD, Kim PS, Alber T. X-Ray structure of the GCN4 leucine zipper, a twostranded, parallel coiled coil. Science 1991;254:539-544. [PubMed: 1948029]

36. Lupas AN, Gruber M. The structure of $\alpha$-helical coiled coils. Adv Protein Chem 2005;70:37-78. [PubMed: 15837513]

37. Harbury PB, Zhang T, Kim PS, Alber T. A switch between two-, three-, and four-stranded coiled coils in GCN4 leucine-zipper mutants. Science 1993;262:1401-1407. [PubMed: 8248779]

38. Lumb KJ, Kim PS. A buried polar interaction imparts structural uniqueness in a designed heterodimeric coiled coil. Biochemistry 1995;34:8642-8648. [PubMed: 7612604]

39. Price JL, Horne WS, Gellman SH. Discrete heterogeneous quaternary structure formed by $\alpha / \beta$-peptide foldamers and $\alpha$-peptides. J Am Chem Soc 2007;129:6376-6377. [PubMed: 17465552]

40. Hintermann T, Seebach D. The biological stability of $\beta$-peptides: No interactions between $\alpha$ - and $\beta$ peptidic structures. Chimia 1997;51:244-247.

41. Steer DL, Lew RA, Perlmutter P, Smith AI, Aguilar MI. $\beta$-Amino acids: Versatile peptidomimetics. Curr Med Chem 2002;9:811-822. [PubMed: 11966446]

42. Hook DF, Bindschädler P, Mahajan YR, Šebesta R, Kast P, Seebach D. The proteolytic stability of 'designed' $\beta$-peptides containing $\alpha$-peptide-bond mimics and of mixed $\alpha, \beta$-peptides: Application to the construction of MHC-binding peptides. Chemistry \& Biodiversity 2005;2:591-632. [PubMed: 17192006]

43. Zasloff M. Antimicrobial peptides of multicellular organisms. Nature 2002;415:389-395. [PubMed: 11807545]

44. Porter EA, Wang XF, Lee HS, Weisblum B, Gellman SH. Antibiotics: Non-haemolytic $\beta$-amino-acid oligomers. Nature 2000;404:565-565. [PubMed: 10766230]

45. Mowery BP, Lee SE, Kissounko DA, Epand RF, Epand RM, Weisblum B, Stahl SS, Gellman SH. Mimicry of antimicrobial host-defense peptides by random copolymers. J Am Chem Soc 2007;129:15474-15476. [PubMed: 18034491]

46. Arkin MR, Wells JA. Small-molecule inhibitors of protein-protein interactions: Progressing towards the dream. Nat Rev Drug Discov 2004;3:301-317. [PubMed: 15060526]

47. Adams JM, Cory S. The Bcl-2 apoptotic switch in cancer development and therapy. Oncogene 2007;26:1324-1337. [PubMed: 17322918]

48. Sattler M, Liang H, Nettesheim D, Meadows RP, Harlan JE, Eberstadt M, Yoon HS, Shuker SB, Chang BS, Minn AJ, Thompson CB, Fesik SW. Structure of Bcl-x $\mathrm{L}_{\mathrm{B}}-\mathrm{Bak}$ peptide complex: Recognition between regulators of apoptosis. Science 1997;275:983-986. [PubMed: 9020082]

49. Czabotar PE, Lee EF, van Delft MF, Day CL, Smith BJ, Huang DCS, Fairlie WD, Hinds MG, Colman PM. Structural insights into the degradation of Mcl-1 induced by BH3 domains. Proc Natl Acad Sci U S A 2007;104:6217-6222. [PubMed: 17389404] 
50. Sadowsky JD, Schmitt MA, Lee HS, Umezawa N, Wang S, Tomita Y, Gellman SH. Chimeric $(\alpha / \beta$ $+\alpha$ )-peptide ligands for the BH3-recognition cleft of Bcl- $\mathrm{x}_{\mathrm{L}}$ : Critical role of the molecular scaffold in protein surface recognition. J Am Chem Soc 2005;127:11966-11968. [PubMed: 16117535]

51. Sadowsky JD, Fairlie WD, Hadley EB, Lee HS, Umezawa N, Nikolovska-Coleska Z, Wang S, Huang DCS, Tomita Y, Gellman SH. $(\alpha / \beta+\alpha)$-Peptide antagonists of $\mathrm{BH} 3$ domain/Bcl- $\mathrm{x}_{\mathrm{L}}$ recognition: Toward general strategies for foldamer-based inhibition of protein-protein interactions. J Am Chem Soc 2007;129:139-154. [PubMed: 17199293]

52. Sadowsky JD, Murray JK, Tomita Y, Gellman SH. Exploration of backbone space in foldamers containing $\alpha$ - and $\beta$-amino acid residues: Developing protease-resistant oligomers that bind tightly to the BH3-recognition cleft of Bcl-x ${ }_{\mathrm{L}}$. Chem Bio Chem 2007;8:903-916.

53. Horne WS, Boersma MD, Windsor MA, Gellman SH. Sequence-based design of $\alpha / \beta$-peptide foldamers that mimic BH3 domains. Angew Chem Int Ed 2008;47:2853-2856.

54. Ananda K, Vasudev PG, Sengupta A, Raja KMP, Shamala N, Balaram P. Polypeptide helices in hybrid peptide sequences. J Am Chem Soc 2005;127:16668-16674. [PubMed: 16305256]

55. Baldauf C, Günther R, Hofmann HJ. Helix formation in $\alpha, \gamma$ - and $\beta, \gamma$-hybrid peptides: Theoretical insights into mimicry of $\alpha$ - and $\beta$-peptides. J Org Chem 2006;71:1200-1208. [PubMed: 16438538]

56. Sharma GVM, Jadhav VB, Ramakrishna KVS, Jayaprakash P, Narsimulu K, Subash V, Kunwar AC. $12 / 10$ - and 11/13-Mixed helices in $\alpha / \gamma$ - and $\beta / \gamma$-hybrid peptides containing C-linked carbo- $\gamma$-amino acids with alternating $\alpha$ - and $\beta$-amino acids. J Am Chem Soc 2006;128:14657-14668. [PubMed: 17090052]

57. Zhao Y, Zhong ZQ. Tuning the sensitivity of a foldamer-based mercury sensor by its folding energy. J Am Chem Soc 2006;128:9988-9989. [PubMed: 16881608]

58. Orner BP, Ernst JT, Hamilton AD. Toward proteomimetics: Terphenyl derivatives as structural and functional mimics of extended regions of an $\alpha$-helix. J Am Chem Soc 2001;123:5382-5383. [PubMed: 11457415]

59. Rodriguez JM, Hamilton AD. Benzoylurea oligomers: Synthetic foldamers that mimic extended $\alpha$ helices. Angew Chem Int Ed 2007;46:8614-8617.

60. Gong B. Crescent oligoamides: From acyclic "macrocycles" to folding nanotubes. Chem-Eur J 2001;7:4336-4342.

\section{Biographies}

Samuel H. Gellman earned an A.B. in chemistry from Harvard University in 1981 and a Ph.D. from Columbia University in 1986. In 1987, after postdoctoral research at the California Institute of Technology, Gellman moved to the University of Wisconsin, where he is currently the Ralph F. Hirschmann Professor of Chemistry.

W. Seth Horne earned a B.S. in chemistry from Texas A\&M University in 2000 and a Ph.D. from the Scripps Research Institute in 2005. He is currently an NIH Postdoctoral Fellow at the University of Wisconsin. 
<smiles>CCNCC(=O)CC</smiles>

$\bar{R}$ $\alpha$-residue<smiles>[2H][C@@H](CC(=O)S)NS</smiles>

$\beta^{3}$-residue

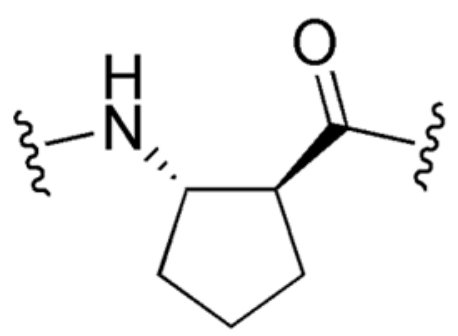

ACPC residue<smiles>O=C(S)[C@@H](P)CNS</smiles>

$\beta^{2}$-residue

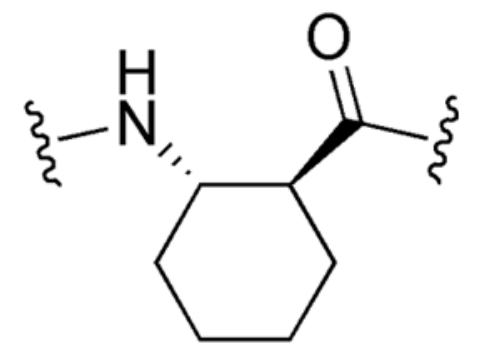

$\mathrm{ACHC}$ residue

Figure 1.

Structures of an $\alpha$-residue along with various $\beta$-residues. 


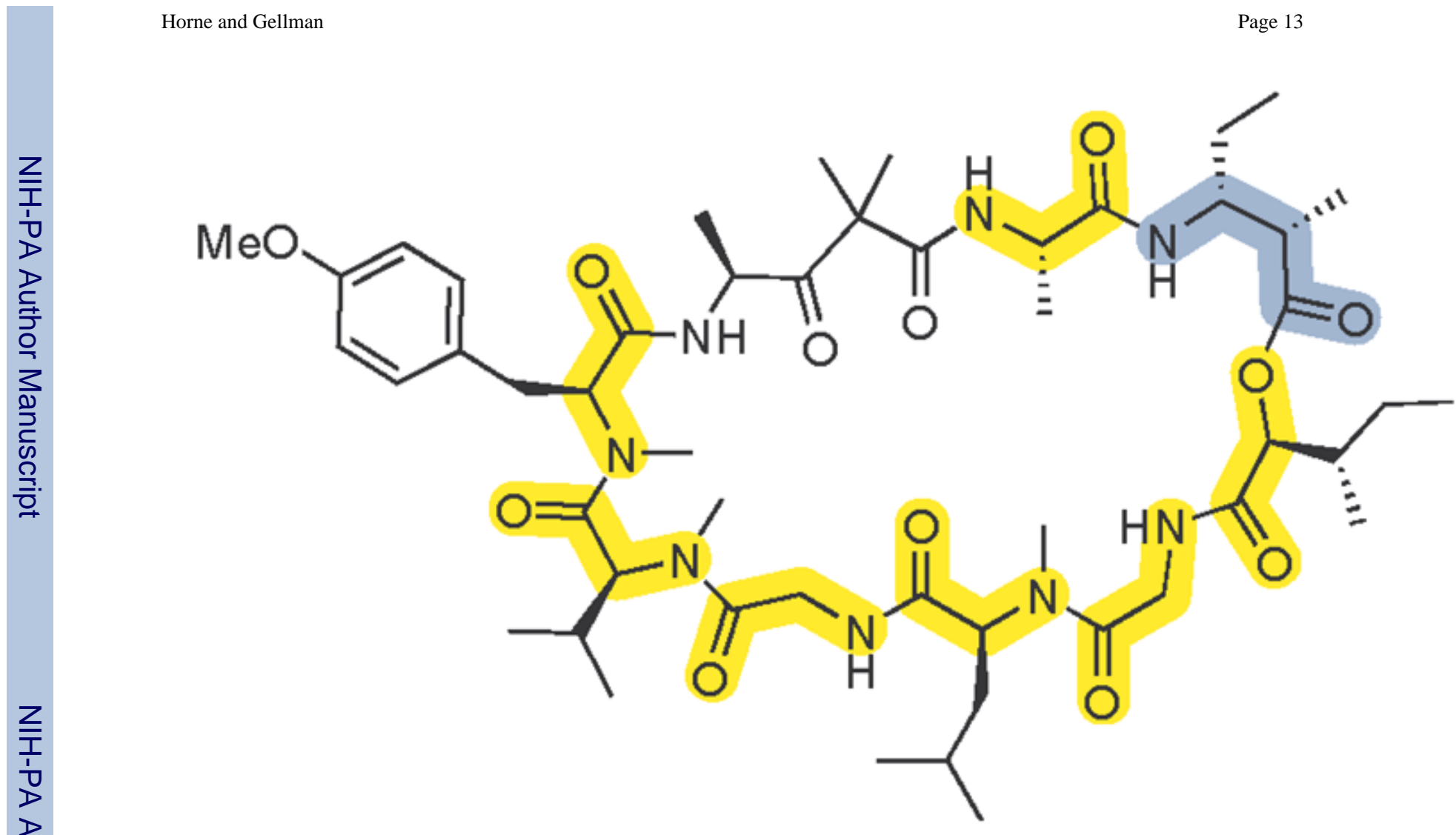

Figure 2.

The natural product Dolastatin $11 ; \alpha$ - and $\beta$-residues are highlighted yellow and blue, respectively. 
(A)

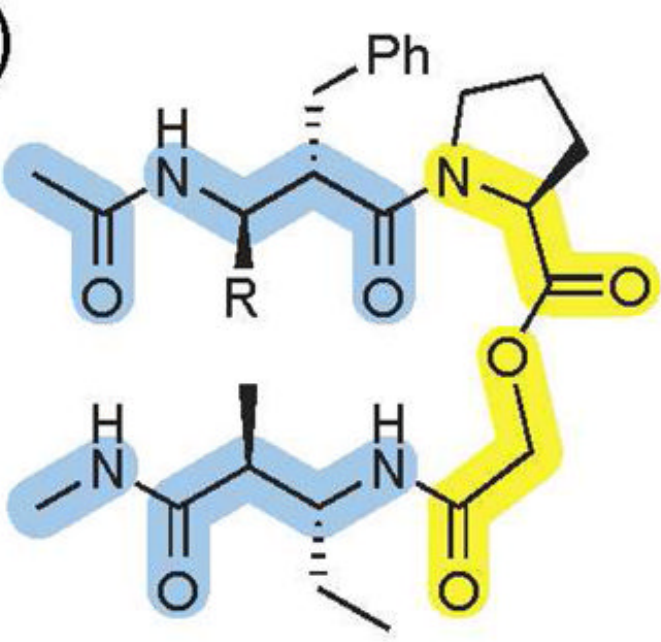

$\mathrm{R}=\mathrm{CH}_{2} \mathrm{SPh}$

(B)

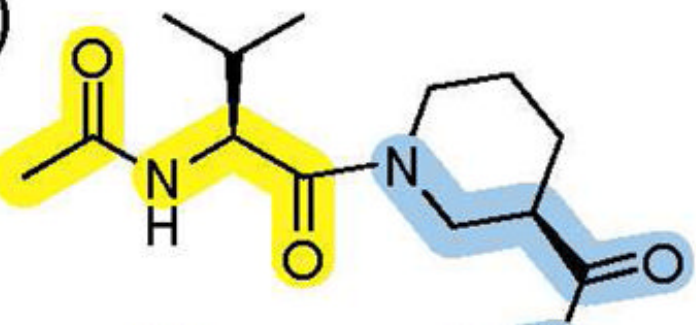

(C)

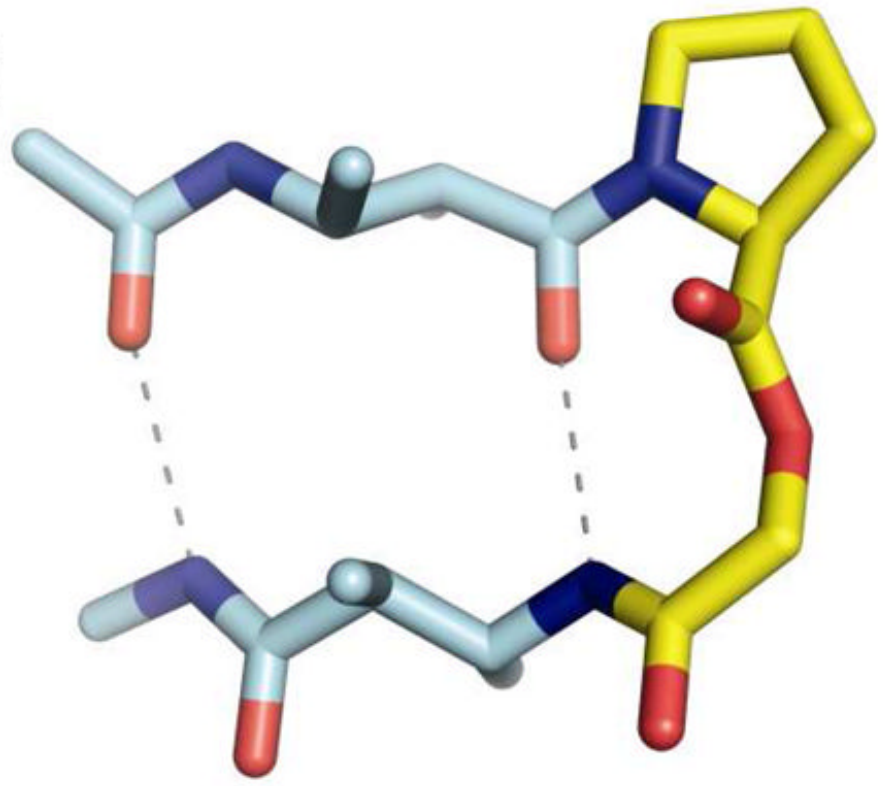

Figure 3.

(A), (B) Chemical structures of two $\alpha / \beta$-peptide hairpins. (C) The crystal structure of the hairpin depicted in (A); some atoms are omitted for clarity. 

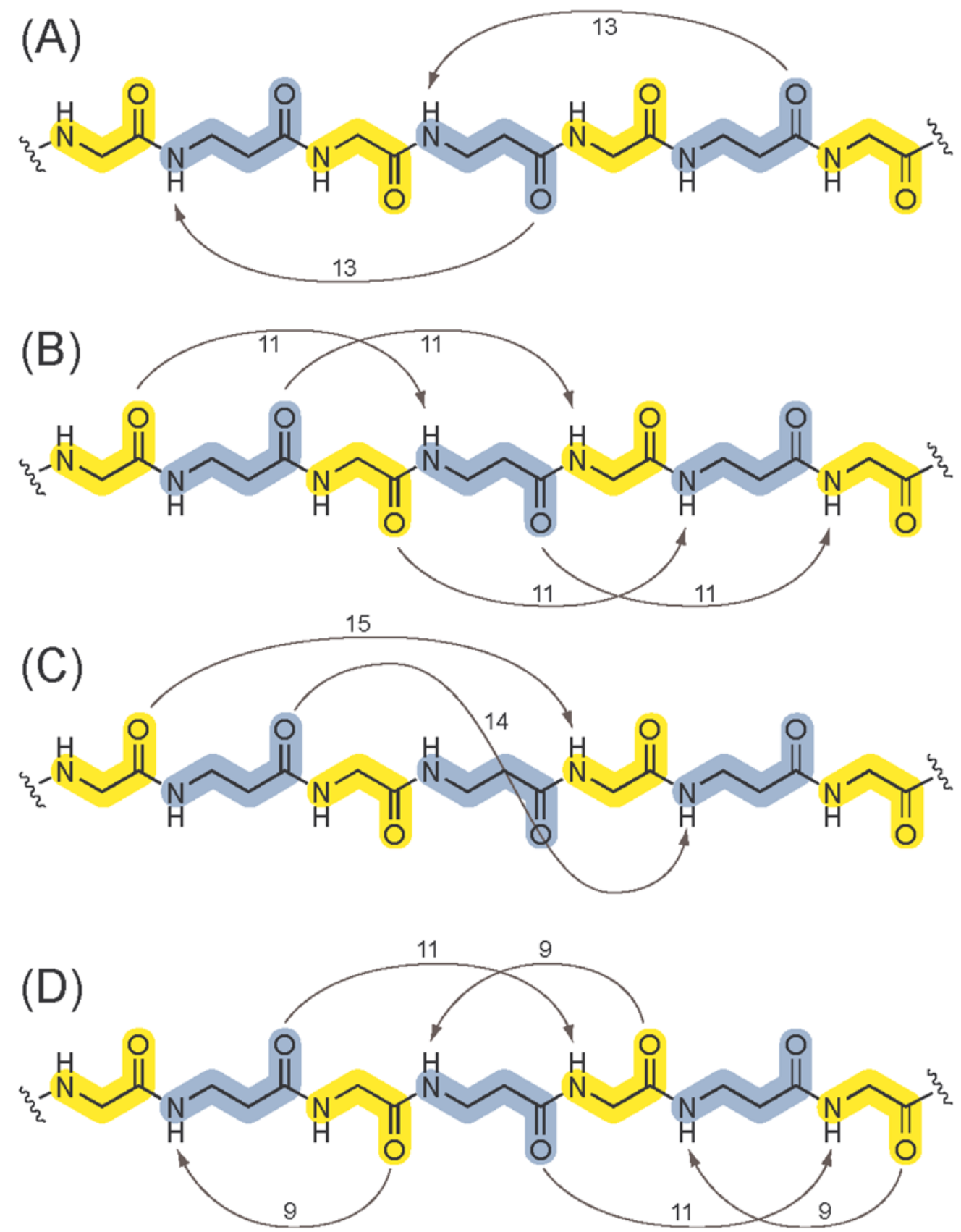

Figure 4.

$\mathrm{H}$-bonding patterns observed in different helices formed by $\alpha / \beta$-peptides with $1: 1$ backbone alternation: the (A) 13-helix, (B) 11-helix, (C) 14/15-helix, and (D) 9/11-helix. $\alpha$ - and $\beta$ residues are highlighted yellow and blue, respectively. 
(A)

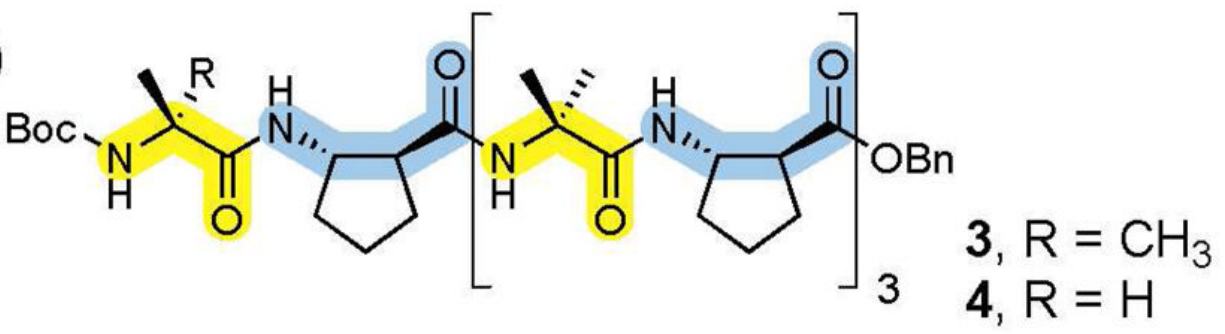

(B)<smiles>CC(=O)N[C@@H](C)C(=O)N[C@H]1CCC[C@@H]1C(=O)NC(C)(C)C(=O)N[C@H]1CCC[C@H]1C(=O)NC(C)(C)C(=O)OCc1ccccc1</smiles>

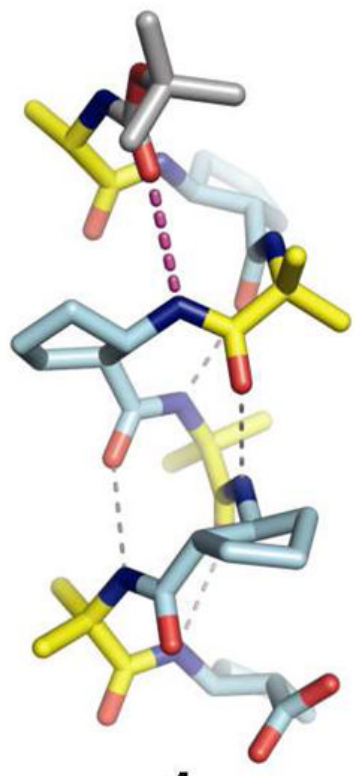

4

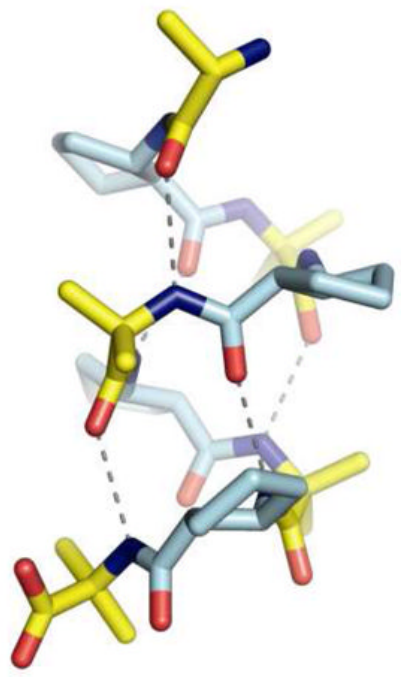

5

Figure 5.

(A) Chemical structures and (B) crystal structures of 3-5. Note the change in the hydrogen bonding behavior of the Boc group (grey carbons) from an $i \rightarrow i+3 \mathrm{H}$-bond in $\mathbf{3}$ to an $i \rightarrow i+4 \mathrm{H}$ bond in $\mathbf{4}$. Some atoms are omitted for clarity. 


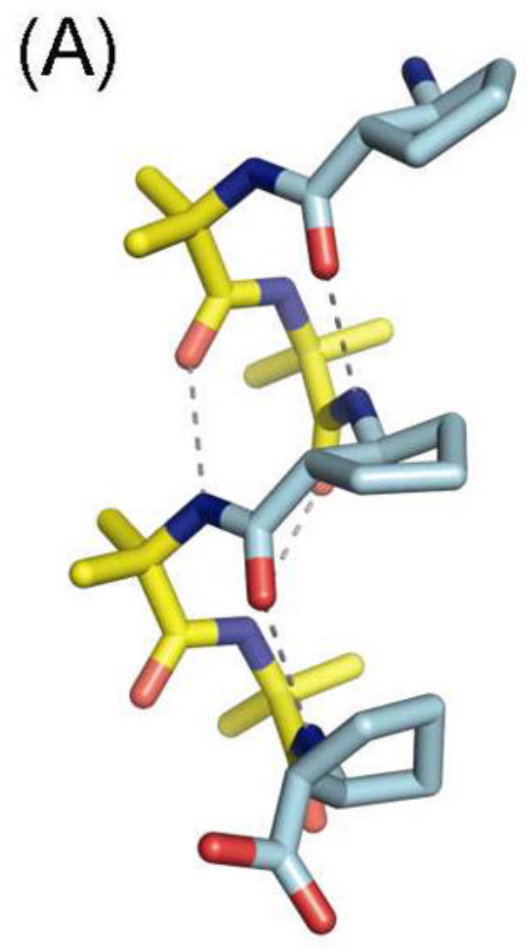

(B)

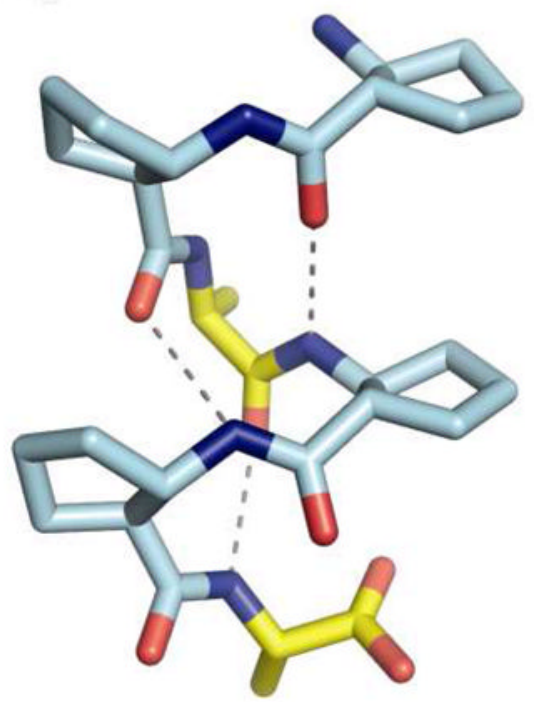

Figure 6.

Crystal structures of short $\alpha / \beta$-peptides with (A) an $\alpha \alpha \beta$ repeat and (B) an $\alpha \beta \beta$ repeat. 
(A)

Ac-RMKQLEDKVEELLSKNYHLENEVARL KKLVGER-OH

(10)

Ac-RMKQIEDKLEEILSKLYHIENELARI KKLLGER-OH

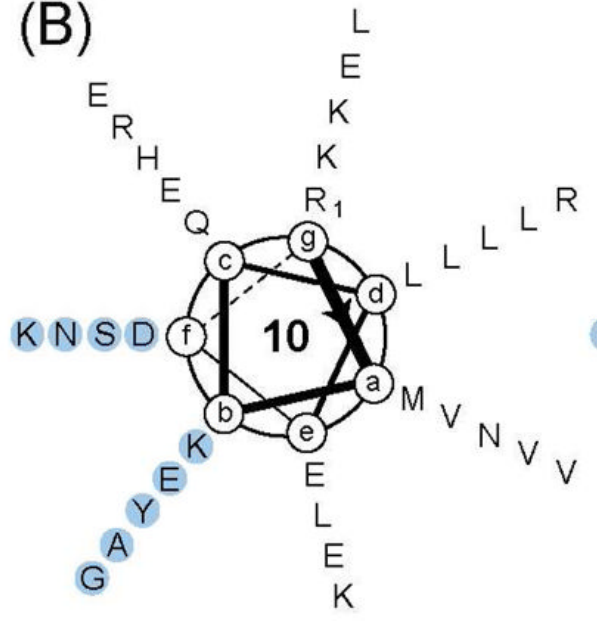

(11)<smiles>[R]C(NCC)C(=O)O</smiles><smiles>[R]C(CC(C)=O)NCC</smiles>
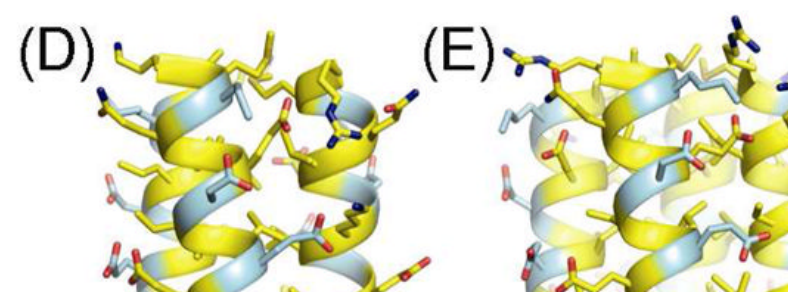

$\mathrm{E}_{\mathrm{R}}$
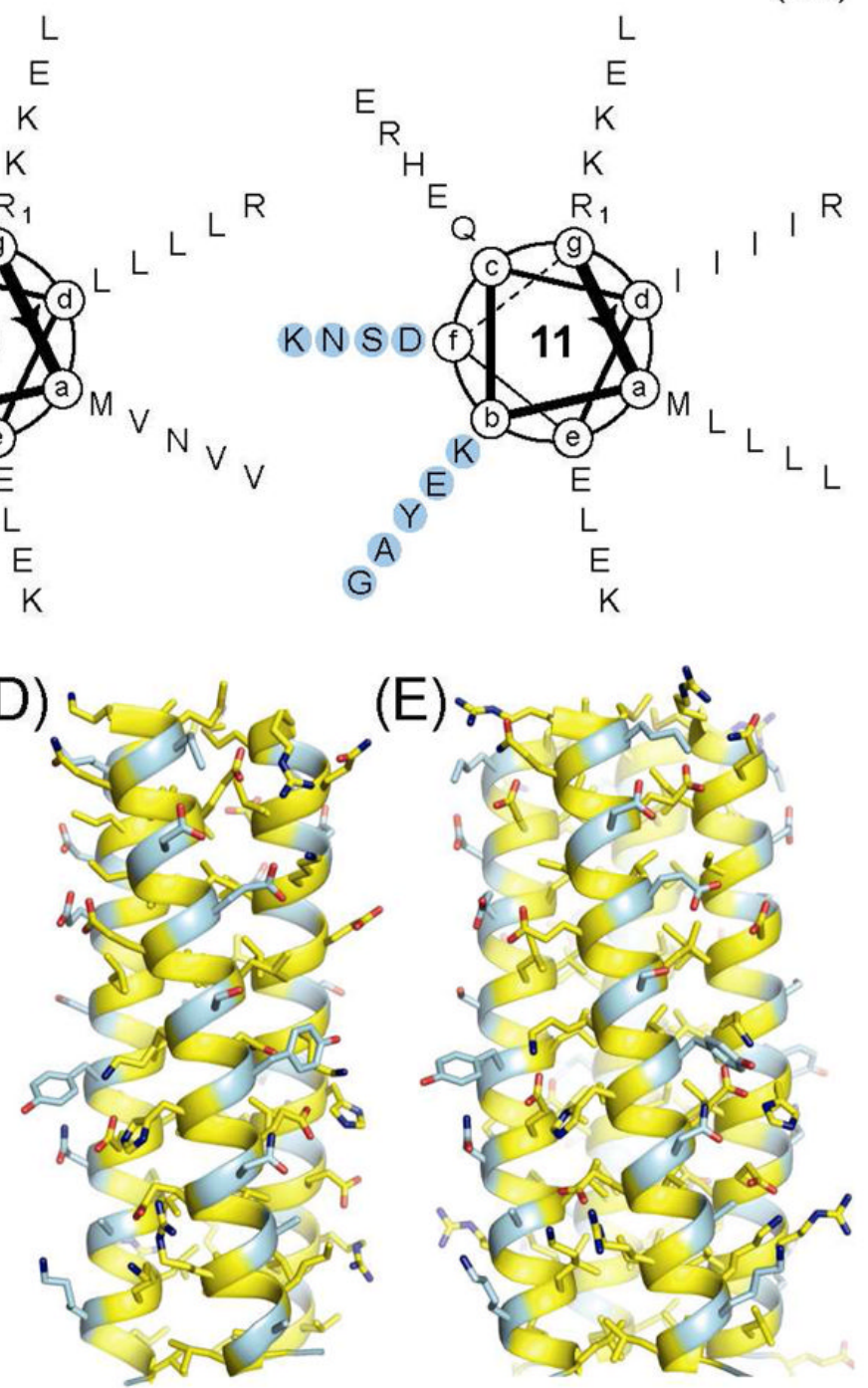

Figure 7.

(A) Primary sequence and (B) helical wheel diagrams of $\alpha / \beta$-peptides 10 and 11; (C) Each blue circle in (A) and (B) indicates substitution of the $\alpha$-amino acid with the corresponding $\beta^{3}$-amino acid. (D), (E) Helix bundles from the crystal structures of (D) 10 (PDB: 2OXJ) and (E) 11 (PDB: 2OXK); $\alpha$ - and $\beta$-residues are colored yellow and blue, respectively. 
(A)

\section{Ac-AQLEKELQALEKELAQLEWELQALEKELAQ-NH}

(12)

\section{Ac-XLZKZLXALKZKLAXLZWZLXALKZKLAX-NH}

(13)

(B)
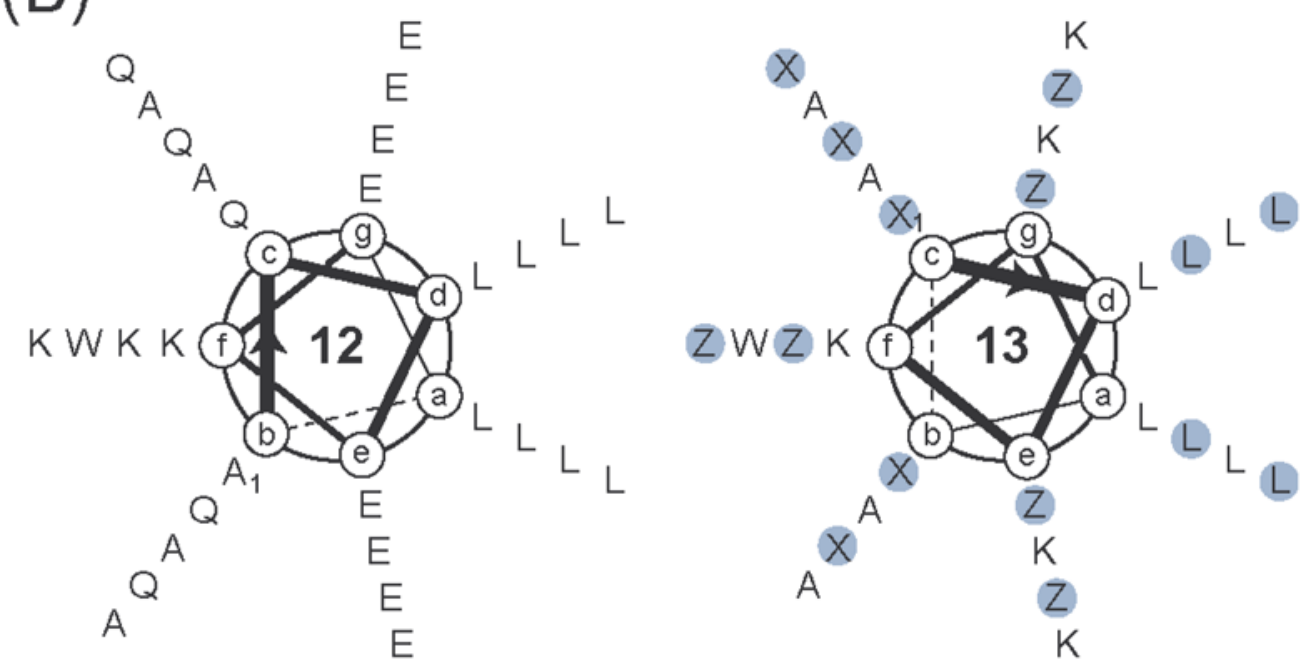<smiles>CCNCC(CC(C)C)C(C)=O</smiles><smiles>[X]C1CC[C@@H](NC(C)C)[C@H]1C(=O)OC</smiles><smiles>CN[C@H]1CNC[C@@H]1C(C)=O</smiles>

Figure 8.

(A) Primary sequence and (B) helical wheel diagrams of $\alpha$-peptide 12 and $\alpha / \beta$-peptide $\mathbf{1 3}$ that form a cooperatively folded hetero-tetrameric helix bundle assembly. (C) Structures of the $\beta$ amino acids abbreviated in (A) and (B). 


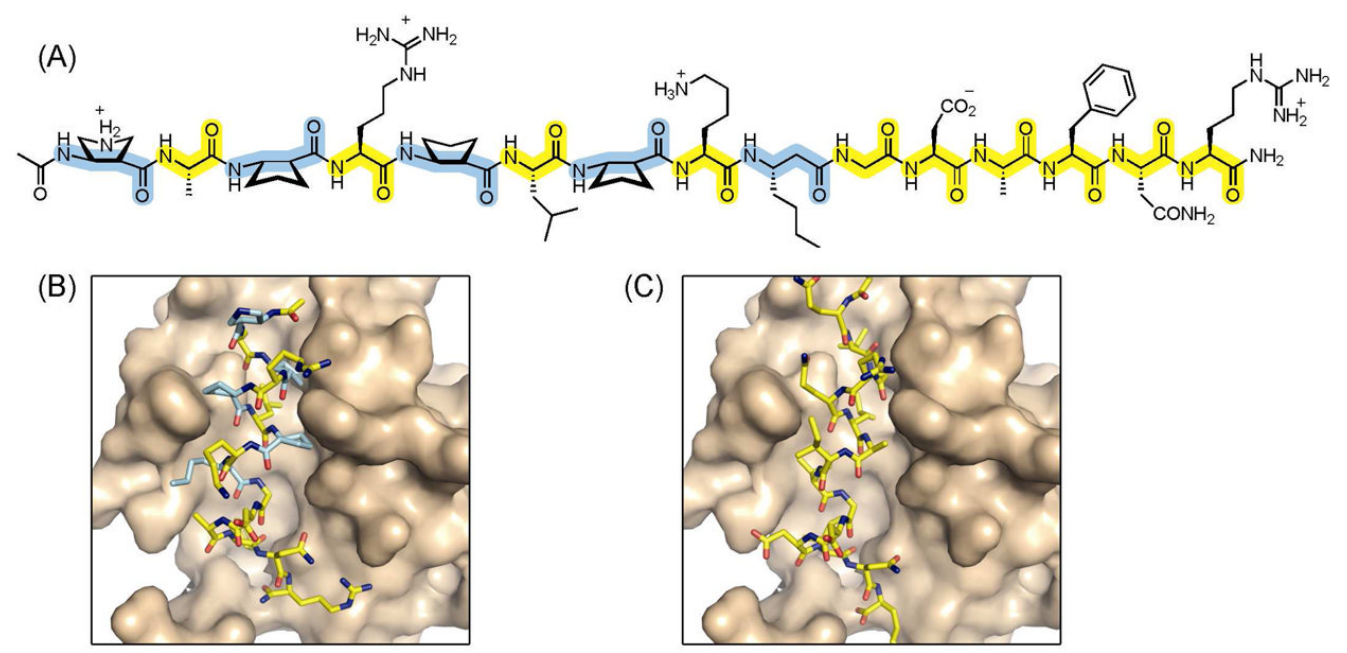

Figure 9.

(A) Chemical structure of 14 , a chimeric $(\alpha / \beta+\alpha)$-peptide with $n M$ affinity for $B c l-x_{L} \cdot(B)$ Binding model for 14 bound to Bcl- $\mathrm{x}_{\mathrm{L}}$ based on docking calculations. (C) NMR structure of Bak $\alpha$-peptide bound to Bcl- $\mathrm{x}_{\mathrm{L}}$ (PDB: 1BXL). 
<smiles>CC(=O)OC(C(C)=O)C(=O)NC(C(C)=O)C(=O)NC(C)C(=O)NC(C)C(=O)NC(C)C(=O)NC(C(C)=O)C(C)N</smiles><smiles>CC(=O)N[C@H]1CCC[C@H]1C(=O)NC(CCCCN)C(=O)NC1CCCC1C(=O)N[C@H](Cc1ccc(O)cc1)C(=O)N[C@H]1CCC[C@H]1C(=O)N[C@@H](CCCCN)C(N)=O</smiles><smiles>COC(=O)C(Cc1ccccc1)NC(=O)CC(NC(=O)C(Cc1ccccc1)NC(=O)CC(NC(=O)C(Cc1ccccc1)NC(=O)OCc1ccccc1)C(C)C)C(C)C</smiles>

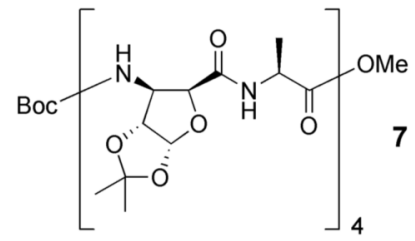

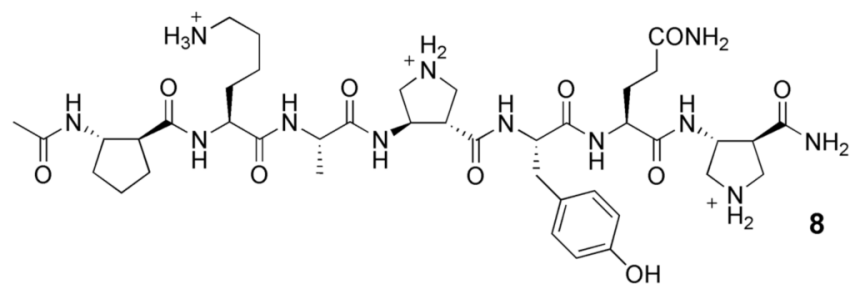<smiles>CC(=O)NC1CCCC1C(=O)NC1CNCC1C(=O)NC(=O)CNC1CNCC1C(=O)NC1CNCC1C(=O)NC1CCCC1C(=O)NC(CCCCN)C(N)=O</smiles> 